\title{
ISLAMIZATION OF CONTEMPORARY ARCHITECTURE: SHIFTING THE PARADIGM OF ISLAMIC ARCHITECTURE
}

\author{
Mustapha Ben-Hamouche
}

Department of Civil Engineering and Architecture,

College of Engineering, University of Bahrain, Bahrain

e-mail: mbenhamouche@eng.uob.bh

\begin{abstract}
Islamic architecture is often thought as a history course and thus finds its material limited to the cataloguing and studying of legacies of successive empires or various geographic regions of the Islamic world. In practice, adherent professionals tend to reproduce high styles such as Umayyad, Abassid, Fatimid, Ottoman, etc., or recycle well known elements such as the minarets, courtyards, and mashrabiyyahs. This approach, endorsed by the present comprehensive Islamic revival, is believed to be the way to defend and revitalize the identity of Muslim societies that was initially affected by colonization and now is being offended by globalization. However, this approach often clashes with the contemporary trends in architecture that do not necessarily oppose the essence of Islamic architecture. Furthermore, it sometimes lead to an erroneous belief that consists of relating a priori forms to Islam and that clashes with the timeless and universal character of the Islamic religion. The key question to be asked then is, beyond this historicist view, what would be an "Islamic architecture" of nowadays that originates from the essence of Islam and that responds to contemporary conditions, needs, aspirations of present Muslim societies and individuals. To what extends can Islamic architecture benefits from modern progress and contemporary thought in resurrecting itself without loosing its essence. The hypothesis of the study is that, just as early Muslim architecture started from the adoption, use and re-use of early pre-Islamic architectures before reaching originality, this process, called Islamization, could also take place nowadays with the contemporary thought that is mostly developed in Western and non-Islamic environments. Mechanisms in Islam that allowed the "absorption" of pre-existing civilizations should thus structure the islamization approach and serve the scholars and professionals to reach the new Islamic architecture. The objectives of the paper consist of counter-criticizing orientalists' views that overwhelm our libraries and references systems, and that consider the first stage of Islamic civilization, within which architecture is part, as a mere cut-and-paste process and, at best, a synthesis of these pre-Islamic heritages, and overcoming the prevailing historicist approach, and open new scopes for future generations to instate a new era of islamization that permits digesting the contemporary Western thoughts in a conscious, critical, and constructive way.
\end{abstract}

Keywords: Maqassid, khilafa, islamization of knowledge, Islamic Architecture, ijtihad, Contemporary Architecture

\begin{abstract}
Abstrak
Arsitektur Islam seringkali hanya dipandang dari sudut pandang kesejarahan, sehingga materi keilmuannya terbatas pada upaya mengatalogkan warisan sejarah dari berbagai kerajaan atau wilayah geografis di dunia Islam. Pada prakteknya, para praktisi cenderung mereproduksi gaya Umayyah, Abassiyah, Fatimiyah, dan sejenisnya, atau mengulang penggunaan elemen-elemen terkenal seperti menara, maidan, atau mashrabiyyah. Pendekatan semacam ini diyakini dapat mempertahankan dan merevitalisasi identitas masyarakat Muslim yang dulu dipengaruhi penjajahan, dan saat ini dikuasai globalisasi. Bagaimanapun, pendekatan ini sering tak sejalan dengan tren kontemporer dalam arsitektur yang ternyata tak selalu bertentangan dengan esensi arsitektur Islam. Pendekatan ini juga terkadang mengarah pada kekeliruan dalam menghubungkan bentuk-bentuk tertentu dengan Islam, dan karenanya bertentangan dengan karakter Islam yang abadi dan universal. Pertanyaan kuncinya adalah, di luar jangkauan pandangan historis, akan bagaimanakah arsitektur Islam masa kini yang berakar dari esensi Islam dan yang merespon kondisi, kebutuhan, dan aspirasi kontemporer masyarakat dan individu Muslim saat ini. Seluas apakah manfaat kemajuan modern dan pemikiran kontemporer bagi arsitektur Islam dalam membangkitkan dirinya sendiri tanpa kehilangan esensinya. Hipotesis penelitian ini adalah, sama seperti arsitektur Muslim awal yang memulai dengan adaptasi arsitektur pra-Islam sebelum mencapai orisinalitasnya, proses islamisasi ini bisa juga berlangsung saat ini dengan pemikiran kontemporer yang sebagian besar dikembangkan di Barat. Mekanisme dalam ajaran Islam yang memungkinkan "penyerapan" dari peradaban sebelumnya dapat menstrukturisasi pendekatan islamisasi dan membantu para ilmuwan dan profesional untuk mencapai arsitektur Islam yang baru. Makalah ini berisi kritik terhadap pandangan orientalis yang membanjiri referensi, yang menganggap tahap awal dari peradaban Islam, dimana arsitektur merupakan bagiannya, sebagai proses penjiplakan dari warisan pra-Islam. Makalah ini juga berisi kritik terhadap pendekatan historis, serta berupaya membuka ruang lingkup baru bagi generasi mendatang untuk menghadapi era baru islamisasi untuk dapat mencerna pemikiran kontemporer Barat secara sadar, kritis dan konstruktif.
\end{abstract}

Kata kunci: Maqassid, khilafah, islamisasi pengetahuan, ijtihad, Arsitektur Islam, Arsitektur Kontemporer 


\section{Introduction: The Theory of Islamization}

Islamization of knowledge is a recent term that was developed by contemporary Muslim scholars in order to bridge the gap between Islam and the various fields of modern thought (Figure 1$)^{1}$. Modern disciplines must be critically examined and their philosophical foundations be recast into the Islamic vision, while the Islamic thought should benefit from the recent progress in methodologies, approaches, instrumentations, and progress in new sciences ${ }^{2}$.

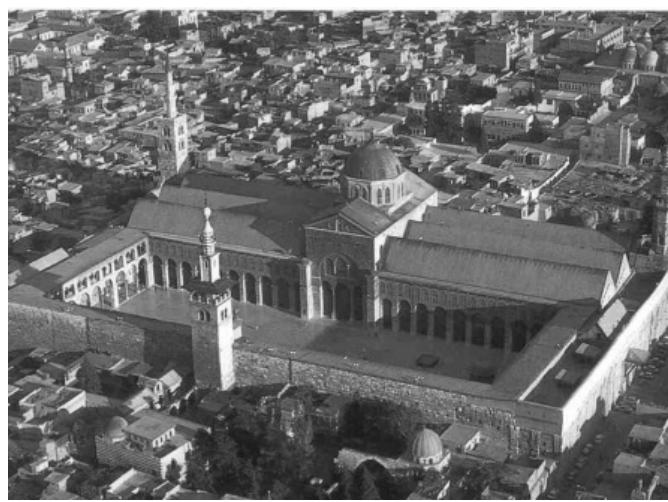

Figure 1. Great Mosque in Damaskus, influenced by the Roman architecture

This vision is best stated by al-Attas as follows:

"We do affirm that religion is in harmony with science but this does not mean that religion is in harmony with modern scientific methodology and philosophy of science. Since there is no science that is free of value, we must intelligently investigate and study the values and judgments that are inherent in, or aligned to, the presuppositions and interpretations of modern science. We must not indifferently and uncritically accept each new scientific or philosophical theory without first understanding its implication and testing the validity of values that go along with the theory. Islam possesses within itself the source of its claim to truth, and does not need scientific or philosophical theories to justify such a claim. Moreover, it is not the concern of Islam to fear scientific discoveries that could contradict the validity of its truth." 3

Modern science has reduced the study of the phenomenal world to an end in itself that brought material benefits, but was, however accompanied by an uncontrollable and insatiable propensity to destroy nature itself. Islamic metaphysics is a unified system that discloses the ultimate nature of Reality in positive terms and would thus correct this trend ${ }^{4}$.

Architecture had always been a field of knowledge in which many disciplines such as history, economy, sociology, technology and arts, meet, cross, and interact. Developing "Islamic or Muslim Architecture" in the contemporary context would thus require a conscious amalgamation of Islamic knowledge with the contemporary thoughts and practices. Old Muslim architecture, as an output of Muslim societies and individuals practices in res- ponse to their beliefs and Islamic teachings, would serve in this perspective as an historical image, and a precedent in the process of islamization that took place in early times of Islam (Figure 2).

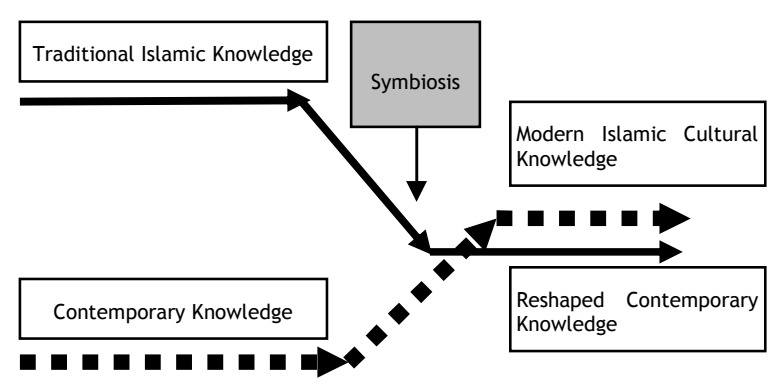

Figure 2. The scheme of islamization of knowledge

\section{Islamization of (Architectural) Knowledge}

The previous approach applies to a large extend to the domain of architecture nowadays both in its theoretical and practical sides. Islam brought a set of values and beliefs, and a way of conduct that shaped the life of communities and individuals in all aspects. However, it didn't provide a pre-defined model(s) of architecture that reflects its teachings. Many buildings, elements, and typologies have been initially adopted from pre-Islamic legacies during conquests periods and early settling of Muslim communities in different regions. It was only lateron that new architectures emerged in a symbiosis between these principles, the pre-Islamic legacies and the necessity for progress and evolution.

Consequently, the revival of Islamic architecture nowadays must not be contented with the return to the "Golden age" nor with the renewal of the old architecture but through the process of Islamization; i.e. the wise adoption and use of existing architectures that is modeled by the Islamic set of concepts. This process has a double role; it enables Muslim societies to bridge the intellectual gap with the West, and to apply the Islamic mechanisms to contemporary legacy in view of reaching a new stage of creativity originality.

The hypothesis is better expressed by Bianca, as follows ${ }^{5}$ :

"It is only by making use of these inner forces that a society will be able to respond to outside challenges, to absorb, adapt, and transform the achievements of foreign civilizations without loosing its own identity".

On elaborating on the approach he considers:

"Establishing a new cultural synthesis through selective and meaningful use of the "raw material" of today's modern civilisation is indeed the major challenge Islamic societies face today. In importance, this challenge is comparable to the situation during the early days of Islam, when the community was confronted with the wealth of Greco-Roman civilisation 
and had to forge an unmistakably Islamic culture under its own spiritual premises."

\section{Is there a Need for Islamizing Architecture?}

The necessity for the return to Islam and thus the need for Islamic architecture could be justified by the cultural crisis that Muslim societies are undergoing. Initially, the degeneration of Islamic values took place due to the long period of colonization. Later on, the Western culture invaded most aspects of life in the Muslim societies through technology, mode of living, economic and political systems, as well as knowledge, a fact that led to the erosion of the latent Islamic values.

The quest for Islamic architecture should therefore be regarded as one side of this multifaceted cultural crisis that imposes itself not only to societies, but also to intellectuals, scientists, and professionals. One way to revive the Islamic values in architecture and grasping the contemporary progress is thus through the process of Islamization.

For architects and professionals, the necessity for Islamizing architecture stems from both theoretical and practical considerations. In practice, an acute needs for "an Islamic physical environment" imposes itself through the demand of individuals and societies for an Islamic environment in the same way as Islamic banking, political parties, teaching, and dressing are emerging ${ }^{6}$. This quest is however, naively expressed in architecture by individuals and communities either through the nostalgic return to old forms and decorations, or through an alteration of modern outputs ${ }^{7}$.

In academia, Islamization of architecture comes from the nature of the discipline itself that reflects culture, sociology and moral values of its users ${ }^{8}$. Islam, as a comprehensive religion has deep, inclusive, and lasting effects on daily life of societies and individuals. It dictates their mode of use and shapes their environment in all aspects of architecture.

In education, many curricula on architecture, in Muslim as well as Western countries, include courses on Islamic architecture in response to the anthropologic and cultural studies, the market pressure, and commercial purposes of the flourishing demand. The teaching approach that often relies on historicism, and the design methodology that ends up with exhibitionist forms often stand short of the profound multi-dimensions of Islam. In addition, such an educational process continuously faces a serious challenge from the ever-emerging Western schools of thought as well as the alien built environment.

Islamization seems therefore to be the way to overcome historicism and exhibitionism. Moreover, Islamization could also bridge the gap between Islamic ethics and contemporary thoughts.

\section{Early Islamization Process and Muslim Architecture}

Initial buildings in Islam were very simple construction of no architectural interest. Ka'ba for instance was a small roofless enclosure, oblong in shape, formed by four walls a little lighter than a man, built of rough stone laid dry, 10 . The prophet's mosque and his house, erected in $622 \mathrm{AD}$, were an enclosure of mud brick that have together about 100 cubits square, surrounded with walls of seven cubits height and covered with a roof that could be touched with hand ${ }^{11}$.

This primitive architecture seems to be very rooted in the Arab pre-Islamic culture. The few Arab dwellers who lived in Mecca and Medina in houses of mud bricks were called ahl-al-madar, while Bedouins who lived in the tents made of camel's-hair cloth were called ahl-al-wabar ${ }^{12}$. Similar state seems however to have continued during the early period of Islamic civilization. Early towns such as Kufa, Basra, and Fustat witnessed during their foundation stage the continuity of this primitive architecture. Despite the planning process and space demarcation of public facilities buildings that were described by historians, most of the buildings were initially tents of reeds that were easily mounted and demounted according to circumstances. That was only after decades that they were replaced by stone buildings ${ }^{13}$.

Beyond the chronologic interpretation of this primitivism, philosophic reasons seem to lay behind the tendency of the new religion to simplicity. The prophet's daily practices and teachings were, according to Creswell, in counter action with any architectural ambition that was often used by rulers and leaders as a symbol of political power ${ }^{14}$. Promoting one's spirit, and adopting Jihad values necessitates renunciation of human desires for wealth, enjoyment, and comfort, and thus decreases the individual's eagerness to architecture ${ }^{15}$.

Despite its comprehensive character that covers all aspects of human life, Islam didn't dictate or prescribe any physical models to its followers. Buildings such as houses, markets and mosques were rather developed along with the Islamic civilization under the pressure of daily needs of users. Many of these buildings were inherited and adapted from the pre-Islamic societies that became part of the Islamic territory after the conquests ${ }^{16}$.

Conquering other countries namely Egypt, Iraq, Yemen, Persia, Shaam, and India that were the nests of early civilizations, was then a critical moment where the confrontation between the Islamic ethics and the materiality of those nations took place, and thus was the birth date of Muslim architecture ${ }^{17}$. A process of absorption, adaptation, ingestion, and internalization of the existing architecture took place $^{18}$. After decades and centuries original forms emerged as a momentum effect of the process. 
Damascus, presents an illustrative example of such a process. Its urban fabric dominated by the Hellenistic-Roman architecture had deeply influenced the Umayyad architecture. The Great Mosque of Damascus for instance witnessed a re-use of the building materials, the adoption of the axial organization as well as the ornaments that were found onsite $^{19}$ (Figure 3). According to historians, Christian masons and craftsmen took part in the edification process of this mosque that became a reference model for a generation of mosques to come, such as Al-Qairaouan and Cordoba.

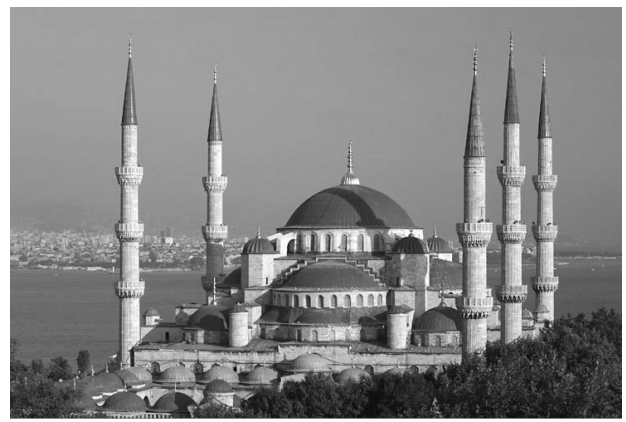

Figure 3. Sultan Ahmet Mosque in Istanbul, influenced by the Byzantine architecture

Constantinople, the capital of Byzantine empire, is another example of such a process. Baths, aqueducts, and public buildings such as Aghia-Sofia, as well as private houses that were integrally inherited by Muslims, had deep impact on the development of the Ottoman architecture during the three centuries of the empire. The huge central dome standing on the large span columns presented an ideal concept that liberates the prayer room and thus turned into a historical prototype that spread all over the Ottoman territory (Figure 4).

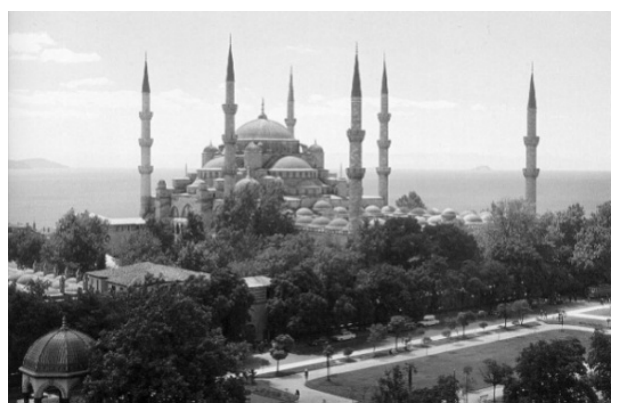

Figure 4. The public building Aghia-Sofia as well as private house that were integrally inherited by Muslims

Persia and Iraq, provided another substance to the Islamization process. The typology of Sassanid architecture, has deeply marked the Muslim architecture of the region. Major elements such as covered markets bazaars, castles, used later on by Abbasids, as well as small elements such as niches called iwans found their way to the Muslim architecture repertory ${ }^{20}$.

The minaret presents a striking example of such an adoption process during the early time of Muslim architecture. Creswell for instance, found that this element has chronologically developed from early towers found in Damascus. It was then spread first to Egypt and then to the other countries that became under The Umayyad governance ${ }^{21}$. Its square base that is used nowadays reflects this chronology and confirms this theory. A similar process with regard to the other types of minarets; namely the cylindrical, octagonal, and the helicoidal forms, took place in Central Asia under the dominance of other dynasties. Regardless of its original function, its pre-existing form was found to fit best the function of Azan and thus was used as minaret ${ }^{22}$. Many other elements such as the mihrab, the minbar, the maqsura, the dome, and the arch that responded to functional, technical, and religious requirements had chronologically their origins back in the pre-Islamic legacies.

Inward looking house could also serve as another example for the process of Islamization ${ }^{23}$. Its spatial organization that pre-existed around the Mediterranean sea, presented an ideal solution to privacy requirement, domestic life and socio-cultural structure of Muslim communities, in addition to its climatic performance.

Opposite to some orientalist interpretations that often stemmed from ideological standpoints consider these historical facts as a proof of a plagiarism from earlier civilizations. Rather, this process should be considered as a reflection of the flexibility of the Islamic doctrine and its responsiveness to human diversity and universal plurality. Existing styles, building technologies, spatial organizations and historical precedents have been amalgamated through the process of Islamisation and gave to Muslim architecture its variety, and to Islamic architecture its essence ${ }^{24}$.

\section{The Matrix of Islamization}

The theory considers that the present body of contemporary knowledge was mostly developed by the Western scholars and institution. It is deeply affected by the Western secular approach and philosophy and consequently, clashes with the Islamic ethics and beliefs. This clash manifests itself most in the summit of the knowledge pyramid in which humanities, social sciences, and philosophy are ranked, but shows less evidence in other experimental disciplines, such as biology and engineering. Filtering and recasting this knowledge in accordance to the Islamic vision is therefore necessary prior to any development project for the Islamic revival and search for progress. 
Islamization of contemporary knowledge is believed to have a double effect. On one side it will have a salvation effect on the contemporary knowledge with regards to its materialist and fragmental tendency that would have destructive effects on humanity and the universe. On the other side, it will inject approaches, instruments, and findings of the new sciences in the body of the traditional Islamic knowledge for the sake of its updating and renewal. Below are the major paradigms that form the Islamization matrix (Table 1).

Tabel 1. Evaluating: A-Accepting, B-Re-conducting, CConditioning, D-Rejecting

\begin{tabular}{|c|c|c|c|c|c|}
\hline $\begin{array}{l}\text { Type of } \\
\text { architec- } \\
\text { ture }\end{array}$ & $\begin{array}{l}\text { Vicege- } \\
\text { rency } \\
\text { Khila- } \\
\text { fa }\end{array}$ & $\begin{array}{l}\text { Islamic } \\
\text { Citi- } \\
\text { zenry } \\
\text { Umma }\end{array}$ & $\begin{array}{c}\text { Legal } \\
\text { Frame- } \\
\text { work } \\
\text { Shari- } \\
\text { aa }\end{array}$ & $\begin{array}{l}\text { Cus- } \\
\text { toms } \\
\text { Urf }\end{array}$ & $\begin{array}{l}\text { Inno- } \\
\text { vation } \\
\text { ljti- } \\
\text { had }\end{array}$ \\
\hline $\begin{array}{l}\text { Regionalism } \\
\text { vernacular }\end{array}$ & & & & A & \\
\hline $\begin{array}{l}\text { Sustainabi- } \\
\text { lity, Green } \\
\text { Movement }\end{array}$ & A & & & & \\
\hline $\begin{array}{l}\text { Modernism } \\
\text { \& Neo- } \\
\text { Modernism }\end{array}$ & & & & & \\
\hline $\begin{array}{l}\text { Decon- } \\
\text { struction, }\end{array}$ & & C & & & \\
\hline \multicolumn{6}{|l|}{ Minimalism } \\
\hline High Tech & & & & & A \\
\hline Modernism & & & & C & \\
\hline $\begin{array}{l}\text { Folklor, } \\
\text { Popular, } \\
\text { Participa- } \\
\text { tive }\end{array}$ & & & & A & \\
\hline $\begin{array}{l}\text { Post- } \\
\text { Modern, } \\
\text { Historic } \\
\text { Revival }\end{array}$ & & & & B & \\
\hline
\end{tabular}

\section{The principle of Vicegerency (al-Khilafah)}

In his article "Faith, Development and the Built Environment", Serageldin considers that an alternative to the rejectionist mode of thinking is grounded in the original sources of Islamic doctrine ${ }^{25}$. There is a subtle danger in initiating the search for a Muslim identity solely in terms of sources. It may lead to a bending of sources texts, ignoring the context, to provide literal guidelines for contemporary action that fit a particular viewpoint. If God desired to give people specific instructions on how to build structures in the twentieth centuries, he could certainly have done so explicitly. Surely no instruction have been given as to the size of rooms or height of doors. Stewardship of the earth is the starting point for the search for a definition of the Muslim approach to the environment based upon God's intended role for men and women ${ }^{26}$. The exercise of stewardship involves two premises. First, the natural resources of this world must be developed so that society may benefit from the rewards of this development (neither minimalist nor exploitationist approaches are valid). Second, a society capable of working this earth must be organized in a just, mutually supportive and balanced manner.

There is an order in the cosmos and in this world that must be respected ${ }^{27}$. This lead to the need for environmental protection, including respect for living creatures of all types.

Regarding muamalat or interpersonal relations, the organization of the society would have the following broad features: freedom, the search for knowledge and truth, action and effort, justice, the public interest, and the concern for the poor and the weak $^{28}$. Contemplative meditation is looked upon as a means of self renewal in order to undertake better tasks in the future not as an end to itself.

Individual behaviour is based on moderation and humility ${ }^{29}$. These attributes seem to be in sharp contrast to much of the ostentatious consumption and self-glorification that are reflected in some of the buildings constructed by those exulted in the newfound wealth.

Quran describes the mission of human on earth as vicegerency to Allah. This mission reflects the belief in the Unity of Creator (tawheed) and the submission to His order. In practice, it consists of making culture and civilization on earth through its colonizing according to the divine commandments ${ }^{30,31}$.

Opposite to the metaphysics that derive from other religions, the unity of the Creator in Islam implies a comprehensive vision to the cosmos and an action framework on earth. This vision could be summed up in the three aspects as follows:

a. The unity of universe, a global image on the cosmos comes out of the puzzling elements such as men, animals, plantations, and other physical entities, and apparently unrelated phenomena such as water and fire, solids and liquids, small and large bodies, good and evils. This unity is also reflected in the cosmic order that consists of the laws of nature ${ }^{32}$. Without this theoretical framework, the universe looks fragmented and mysterious, and man feels that he is surrounded with loss and chaos, an image that draws itself from the present secularism ${ }^{33}$.

b. The unity of humanity, in its history, presence, and destiny. The Khilafa concept connotes the 
mission of all mankind on earth, and doesn't concern Muslims only ${ }^{34}$. In Islamic metaphysics, the human life on earth is bound within the two major events; the starting of the creation from a same off-spring and origin; and the unknown future that will end-up with the inevitable End. The cosmos is thus shared by all nations and societies regardless of their gender, race, ethnicity and religion ${ }^{35}$.

c. The unity of knowledge, that implies the convergence and interaction of all fields and branches of sciences and disciplines, despite their multiplicity, to one central truth. This truth is the essence of existence that reflects the summit of the pyramid-like form of human knowledge and that transcends its branches. According to $\mathrm{Nasr}^{36}$ and al-Attas ${ }^{37}$; the multiple forms of nature are reflections of the Unity which is both the origin and the end of the order of multiplicity ${ }^{38}$. Achievements in different fields of sciences are thus considered as an uncovering process of natural laws, sunan, and are therefore a common wealth of mankind. In engineering for instance, the laws that rule design of any kind are the laws of nature that all boil down to the fundamental principle of unity that pervades all creation ${ }^{39}$.

One of the recent interpretation of this concept is that of Hussain $\mathrm{Nasr}^{40}$. Khalifa concept is fundamentally compatible with ideals of the ecology and peace movements that aims at protecting environment from unwise use. In its Quranic sense it connotes rational use of resources and energy, prevention of harm, and protection of human species. A unity amongst the faiths by concentrating on their common respect for life i.e. the Earth's biosphere, though a "global ethic" is therefore needed.

Precedents in the built environment ${ }^{41}$, building experiments ${ }^{42}$ and architectural thoughts ${ }^{43}$ could in its rough form be considered as a form of 'Imarat al-ardh', and a human experience that instantly aspires to a better environment and well-being.

\section{The Concept of Islamic Citizenry (Umma)}

Islam unifies Muslim societies under one cover that is the Islamic community, Umma. This concept represents a social order that regulates the conduct of social groups as well as individuals within the large entity and with regards the other non-Muslim nations. Regardless of its political dimension, it prescribes a well-organized social life that reflects the collective conduct of Muslim individuals and groups in pair with Islamic commandments ${ }^{44}$. At a smaller scale, the concept of Umma on recognizing equality among the ethnic groups that constitutes it, and the individuals, provides rules and norms that regulate their social conduct and inter-relationships.
Neighborhoods, social aids, humbleness and individual freedoms are principles that constitutes the body of the paradigm of the Umma.

Nowadays, the socio-cultural role of architecture reflects to a large extent the Western ideology. It channels class divergence, competitiveness, materiality, profit-making, exotics, desires, and absolute freedom. In the Islamic context it represents to a Muslim architect a God-given talent that is outlined by the Islamic ethics, and to the user a wealth to be consumed reasonably, and to be regulated by the socio-cultural considerations such as cohesion, humbleness, and reasonable use. Both its artistic and functional sides are thus ruled by the moral, cultural, social, and environmental exigencies of the Islamic citizenry.

\section{The Shariaa and its Supreme Ends (al-Maqassid)}

Al-Shariaa theory is based on a matrix of Ends and priorities that summarizes the essence of the Islamic doctrine. It presents to jurists and scholars a framework that structures the Islamic thought and reasoning process though which human actions are evaluated and judged. Religion in its broader term covers all aspects of human life and aims to protect its essence.

The supreme Ends that constitute the body of Shariaa that were established by early scholars are five; the Religion, the Human Life, the Reason, the Procreation, and the Wealth and Property. Recent studies concluded that some Ends that are at present of crucial importance were not considered in this matrix although they were clearly stated in the Islamic doctrine. For instance, Freedom and Earth in their different senses and hierarchic meanings, are Ends that should be added to the previous matrix ${ }^{45}$.

Besides its legal utility that mostly responds to jurists and scholars reasoning, this matrix also serves to detect, establish, and rank the human needs such as housing, education, food, and dressing. In the case of a housing shortage for instance, the provision of shelter should pass before any other considerations of harmony and aesthetics that often characterize present housing policies.

An architectural project for a night club and/or a bar in the Muslim community, even if it is inspired from local architecture, approved by a Muslim ruler and used by Muslim individuals, is thus considered illegal as it clashes with the supreme Ends, mainly the moral values that are parts of both the Religion and the Procreation Ends. It is not, as is considered in the West, part of the sphere of individuals' freedom.

Similar classifying is also made within each End. Three levels could be identified in accordance of importance; the Utility, the Necessity, and the 
Luxury and Pleasure. This matrix could also be of use for professionals in assessing actions in the built environment and establishing urban policies. In a mosque for instance, the construction of a minaret is considered as a luxurious elements compared with the prayer space. Also, public authorities would have the right of acting on private properties through compulsory purchase for broadening a narrow road for circulation purposes, but could not do so for leisure purposes such as landscape and entertainment spaces.

\section{Urf Principle}

The term in its literature meaning could be translated to: the set of traditions, customs, habits and practices established in a given society. Jurists of Sharia' considered it as one of the pillars of Islamic law and a major source of legislation in the absence of direct texts ${ }^{46}$. Its origin goes back to many Quranic verses and prophets' practices ${ }^{47}$. A condition however for urf to be considered as a source of rightful actions is that it should not clash with the principles, teachings, and guidelines of Islamic doctrine. Otherwise, it is considered as an unlawful custom; Urf Fassid. In practice, urf consists of accepting all existing customs, traditions, and prevailing habits in a given area as far as they don't clash with the essence of religion.

Al-Shatibi defining it as habits ${ }^{48}$; awai'd, classified it into two types, (a) the universal habits that apply to all times, locations, and cases, and (b) the local ones that differ in accordance to regions, times and cases. Precedents in transactions, wording in con-tracts, dressing, dwelling, conducts in a community are of the latter type.

Urf principle could be regarded as a legal framework that allowed local cultures and identities; in all their aspects such dressing, crafts, languages and conducts in different Muslim communities to survive, develop and cohabit with each other and consequently, form the mosaic-like pattern of Islamic civilization. In geo-political terms, it played a double role; maintaining the unity at a small scale; i.e. within the social groups within which non-Muslim communities, and creating diversity with other entities at the largest scale. Its broad and timeless character provides an important margin of flexibility over time, to Muslim individuals and groups in developing, importing and/or adopting new customs that reflect emerging practices and lifestyles. In other terms, it is the magic mechanism through which Islamic religion reaches balance between universality and regionalism, a balance that is still under search in the modern ideologies and theories ${ }^{49}$.

Its implications on building practices, architecture and city making is a fresh field of study that could open new perspectives on the origin of elements such as the minaret, the courtyard, and the different types of windows, as well as the typomorphology development of urban fabrics and cities in the Muslim territories. Current practices in housing and space use socially adopted by contemporaneous Muslim communities from other cultures, or developed out of the clash with modernity, could also be a fertile subject to these studies ${ }^{50}$.

According to Rapoport ${ }^{51}$, a cumulative process of habits and traditions would have taken place over successive civilizations that turned over time into precedents. All people have taken from their precedents in all environments, in all cultures and in all periods.

\section{ljtihad Principle}

It is a legal term that connotes the reasoning that achieves a juridical opinion or legal decision in the absence of direct and clear fundamental texts. It also means the exercising of one's mental effort "Juhd" with regards an unprecedented event or issue to achieve the optimum opinion that matches with the Islamic principles. Only knowledgeable persons and scholars are thus permitted to exercise ijtihad.

While innovation, bida' $a$, in the religious sense such as in prayer, fasting, and hajj is strictly prohibited, it is widely accepted and recommended in the other domains of life, such as political systems, education, and daily practices. Inventions, innovations, and adoption of alternatives in architecture and in other fields of knowledge and practices could thus be considered as a form of ijtihad that aspires to improve the conditions of life.

One of the most obvious fields of ijtihad in Islamic civilization in relation to arts and architecture was geometry that was viewed as an important field of knowledge and that thus, was placed at the same level as mathematics, medicine and astronomy. Important developments in the fields of geometry resulted from the works of Umar al-Khayam, alBuzajani, al-Khawarismi and Ibn al-Hatham in response to land surveying, astronomy, subdivision law i.e. mawarith, and contemplation that goes beyond the material world. Manuals were written to explain basic geometric principles and their applications in these fields ${ }^{52}$.

Islamic decorative designs were interpreted as a visual manifestation of the Islamic philosophy. A circle for instance is considered as a symbol of tawheed, unity of God. Others considered arabesque and Islamic pattern as a "special state of mind". Such interpretations were criticized as lacking methodological rigour and any contextual evidence. 


\section{Application to Contemporary Architecture}

Sections below will focus on the analysis of the most prevailing thought in contemporary architecture in the light of the principles stated above. Although most of these thoughts are tightly linked to the historical evolution of Western societies and thus derive their essence from the dynamics of Western knowledge, it is believed that their confrontation with the Islamic reasoning could be of interest. Points of conflict and concord would ease the process of Islamization of these thoughts as described earlier. Contemporary movements in architecture are presented in a historical sequence and then discussed in the light of the Islamic principles ${ }^{53}$.

\section{Modern Architecture: Universality and Rupture with the Past}

Modern Architecture is considered as a starting point in the history of contemporary architecture. Pioneers of this movement have established a movement that marked the built environment of our present cities over the world as well as the teaching and profession of architecture to nowadays.

One of the basics of modern architecture is its claiming of universality. The forced unification and standardization of human needs, the reliance on the industry and technology in responding to these needs and the uprooted discourse made of its thought an easy target to critics that overwhelmed its partial success in the construction technology, building process, and the mechanical innovative solutions.

Modernism also expressed the blind belief in the Man as the master of his destiny. Human beings can control his life and the cosmos through his mind, the source of sciences and technology. God has dead. The zealous belief in the architects' talent has proven its limitation through its effects on the physical environment, society, and individuals.

Modernization has also been rejected for neglecting self-worth, identity, and animistic life on promoting mass-production, consumerism, and decontextualisation. On the community level, the belief in social engineering was found to be a mere utopia.

Such critics could be of importance to the modern Islamic culture that shares the universal scene in most of the large scale experiences such as housing, economy, education, etc. Universality for instance is also claimed in the Islamic thought. Most values such as privacy and neighbourhood and beliefs are believed in Islam to be timeless and worldwide. However, their consideration in traditional architecture has been adapted to diversity as requested by local conditions, a fact that created a balance between universality and regionalism. A review of this concept in the light of the modern experience might therefore help Muslim scholars assess the scope of universality in the Islamic thought. Opposite to the "extreme" regionalism, a global set of values and basic needs for instance could come up in this regards. In history, many styles and architectural elements, have been spread over the vast territory of Islam during the great dynasties such as Umayyad, Abbassid, and Ottoman due to the cultural interactions between diverse regions. However, the hegemony of a Supreme Culture as it is happening now under globalization may led to similar consequences as modernism.

\section{Post-Modern Movement: Return to Urf and Semiotics}

As a rule in the emergence of architectural trends in the West, each movement seeks to overcome the mistakes of the other traditions and schools $^{54}$. Postmodernism is an overall concept covering several approaches to architecture which have evolved in reaction to modernism ${ }^{55}$. In reaction to the mechanization of architecture, it introduced the science of meaning of forms, considering that architecture is a language perceived through codes. Historicism, symbolism, and user participation were thus reintroduced in the design process as the only way to regenerate meanings, sense of place, and identity ${ }^{56}$.

In the light of Islamic thought, post-modernism could be considered as a re-positioning of the extreme novelty and the re-considering of the social and cultural reality, that are part of the theory of Urf. The return to the forces of traditions and customs in architecture is in fact widely adopted by architects in the Muslim world. However, such an approach under the pressure of the strong nostalgia that characterizes Muslim communities, under the effect of the glorious past, post-modernism often leads to mimetic. In the Gulf for instance, windcatchers are often added to buildings in the presence of powerful air-conditioning giving the flavour of a local architecture regardless of the real meaning of those elements.

An anthropologic approach and deep understanding of the essence of traditional elements, spatial organizations and typologies could thus counter-act the formalist tendency in postmodernism. Other Islamic principles could serve for questioning the utility for the re-use of legacies.

\section{Neo-Classicism: The Way to Reconsidering History}

This movement that rose in reaction to modernism highlights the return to the past practices, urban history and architectural precedents as a source of inspiration. Neo-classicism stresses the virtues of harmony, purity, calm, reason and wisdom 
that characterized the old pre-industrial societies ${ }^{57}$. According to Sir John Summerson value is in deriving theory from history chronologically as the history of ideas $^{58}$. According to the classicist thought, early architectural order that was developed in old time is timeless. It reflects the laws of nature. A reliance on historical determinism to show the relevance of the so called lessons of history is thus necessary ${ }^{59}$. In other words, the value of the history is what it teaches us about the future ${ }^{60}$.

Initially, Neo-classicism was limited to the high style of Greco-Roman legacy that was judged as an invaluable heritage that modernism neglected. It then enlarged its scope to vernacular and preindustrial legacies.

Inference from history and precedent facts as a source of knowledge that would serve the present and guide to a better conduct could be easily proved in Islamic thought ${ }^{61}$. Back-thinking tadabbur and deduction i'tibar are often stated in the Quran as a source of wisdom. Generalization could be made from precedent experiences ${ }^{62}$.

Architecture in this sense is the trace of previous nations on earth that should be considered as a raw material for this "recurring thought" and inference. Beyond the series of events that constitutes the body of history, a hidden cycle that is formed of rules of nature, geographic conditions and social practices governs these events ${ }^{63}$.

As a design approach, major imperial styles such as Umayyad, Abbasid, Fatimid, or Ottoman could for instance serve as a body of historical data that precede an architectural project, in view of applying Neo-classicism to Islamic architecture. However, such an approach, and similarly to postmodernism, often leads to the recycling of old form regardless of their essence, usefulness, and thus turns into a mere fashion.

\section{Minimalism: A way to Renunciation and Contemplation?}

This movement stems from the reaction of modern architects to the school of Beaux Arts in which buildings were over-charged with materials, details, and decorations. It seeks to achieve a balance between architecture and nature through simplicity of form, surface, and detail ${ }^{64}$. In a step beyond simplicity, Tadao Ando for instance focuses on nature itself that is very troubled today. Abstraction is an aesthetic based on clarity of logic and transparency of concept, while representation is concerned with all historical, cultural, climatic, topographical, urban, and living conditions ${ }^{65}$. Architecture in other words should become the simple black screen that forces people to look elsewhere and give chance to contemplation ${ }^{66}$. Light, water, earth, vegetation, landscape, and cosmos should then replace the artificial order and art often provided by the architect to the user.

In Islamic philosophy, as it is also in Christianity, minimalism could be interpreted through the analysis of the two concepts; Zuhud (asceticism, renunciation) and taammul (contemplation, meditation), that both found their practice through Sufism. The first concept requires a withdrawal from the material world and a minimum existence in the sake of spiritual transcendence ${ }^{67}$. It is believed that the physical environment, the surrounding, and the routine of the daily life often screen the mind from reaching higher level of abstraction. Architecture as part of the material world, should have thus minimum consideration in the Muslim mind and concerns. Maximizing comfort, consumption, and joy goes in opposite direction to this thought ${ }^{68}$.

Minimalism in Muslim thought might also be reflected in the house of the Prophet (pbuh), his mosque in Medina as well as the form of Ka'ba', a fact that was considered by Creswell as a "desinterest" in architecture. On designing a mosque for instance, it is recommended that its interior should be left without decorations and aesthetics, as this latter would have an adverse effect on contemplation and reverence, khushuu', that is the essence of prayer $^{70}$. Fully decorated mosques were considered as a sign of degradation of faith and attachment to futilities.

This simplicity and minimalism spirit seems also to have been the essence of the nomadic life during the early time of Islamic civilization. The tent was the minimum shelter that preceded most early cities such as Kufa, Basra, and Fustat ${ }^{71}$. It was then followed in most of houses in old cities such as in Ghardaia, Sudus, and desert settlements. Building materials and construction elements are generally the only aspects of decoration. Rooms are multipurpose spaces that have little and very light furniture. This was the tradition in most houses in the Islamic world before the advent of modernity and industrialization that brought heavy and fixed furniture.

Openness on the sky would also be considered in this regards as a form of minimalism that induce contemplation. All buildings, such as houses and mosques were designed with courtyards at the centre to provide users with a portion of sky. Most often, these courtyards served as a piece of landscape that gathers natural elements such as light, water, plantations and soil. Such a typology and spatial organization would obviously stimulate contemplation more than high rise building that offer a horizontal view on street and neighbours.

However, minimalism as practiced under secular thought, would lead to a "naked" architecture that disregards privacy and domestic life, and spoils energy. Farnsworth house, designed by Mies Van der 
Rohe is for instance clearly in contrast with community values of human being let alone the moral values of Islam. Glass boxes often exhibits high technological performance that often disregards the heavy running costs of energy consumption and costly maintenance.

\section{Deconstruction Movement: The Controversial Approach}

Deconstruction is in a sense a continuity of rupture with the past that the modern philosophy promoted. However, in contrast to the oversimplicity of modernism, deconstruction movement promotes complexity, that too often connotes irrationality and destruction ${ }^{72}$.

Regardless of the simplistic game of fragmented forms and irrational geometry, deconstruction movement in literature has however, the merit of promoting, or at least exploiting, the new sciences of complexity ${ }^{73}$. The recent theory of chaos and fractals that puts an end to the scientific determinism, causal linearity, order, Cartesian geometry, and mathematical rationality, shifted the Western spirit to the humbleness of incertitude ${ }^{74}$.

Atheism that often refuted metaphysics and divinity and that had intrinsically accompanied modern knowledge had thus been deeply shaken. According to Prigogine, "It would have been better to remain attached to the belief in (God) rather than being slaves to the fate of physics,"75.

In social sciences and politics, deconstruction philosophy explores freedom and anomalies to undermine and throw into doubt those systems of power, authority and knowledge privileged by reason, science, and tradition ${ }^{76}$.

In Islamic thought, human knowledge is always considered as partial and relative in comparison to the absolute reality that only God possesses it. On observing the laws of nature, the Quran challenges the human mind through many verses ${ }^{77,78}$. However, throwing confusion in the values, texts, and existence might be rejected due to its destroying effect on culture, beliefs, dogmas, most of which are considered revelation and beyond the scope of mind; Ghaib.

Destroying logo-centrism promoted by semiotics, the essence of post-modernism, could be a departure point to a brainstorming approach on reviewing traditions and customs. Shaking settled beliefs, theories, and traditions as far as these are not revealed constants would affect their permanence and thus may lead to innovation, creativity, and dynamics. A multiple interpretation of a same text for instance may generate new ideas and unprecedented explanations. Verses of the Quran could in this case be subjected to continuous fresh interpretations within the framework of the Islamic doctrine as well as the new scientific achievements and discoveries.

In urban analysis, deconstruction also provides a recurrent approach to the sediments of architectural forms and urban fabrics that cumulated over history. Only by de-layering, that is deconstructing, the urban forms that their generation process could be understood. Computer systems, chaos and fractal theory could help to a large extent in the deconstruction of the complex forms and geometries of old urban fabrics.

Approaching architecture through deconstruction theory may also mean allowing complexity in the process of design that stems from contradictory interests and attitudes of users needs, wishes aspirations as well as the conditions of sites and technical requirements. Opposite to the pure game of ideal forms and abstract order of the still-standing modern approach, deconstruction changes the design paradigm to complexity that reflects the real world as it is, not as it is thought. Deconstruction theory may for instance provide means to understand the apparent contradiction between the pure geometry of patterns and the straight path philosophy ${ }^{79}$, and irregularity that is often considered as chaos and disorder and that characterize the old urban fabrics of Islamic cities. The straight line and the perfect Islamic patterns are the output of the pure thought and the abstract forms of geometry, whereas the irregular geometry of urban fabrics represents the clash of these pure geometry with the constraints of the site, topography, and preferred directions with regards to winds, sunlight, and Qibla direction. Complexity in Muslim architecture and cities would thus be better understood as a metamorphosis of the pure with impure forms, Cartesian with fractal geometry, abstraction and reality ${ }^{80}$.

\section{High-Tech: Innovation and Search for Highest Performance}

High-tech reflects the aspiration of the human mind for perfection though technology and continuous innovation. High-tech pioneers believe that in pushing the technology to its extends problems facing human-being will find their solutions within the continuous problem-solving process. Technology is in other words, the paradigm of our present knowledge and its End, and is thus the only way to remedy the human malaises and improve the quality of the built environment and life. Life cycle might be represented in the light of this theory as a continuous jump in the unknown future that will depend on the innovation and discoveries that human mind achieve under the pressure of crises and aspirations.

Despite the unprecedented progress in technology and its promising potential to solve problems in 
various fields, it cannot embrace all aspects of humanity and complexity of life. Achievements since the industrial revolution have shown that technology, although its aspiration for performance and rationality, and it recent claims of smartness, is often harmful to ecosystem. Reliance on high-tech should thus not be absolute. A place should be made to other considerations such as social wisdom, religion, and nature.

In Islamic thought, high-tech might be considered as a branch of ijtihad that aspires to achieve maximization of human reasoning within the framework of Islamic doctrine ${ }^{81}$. Biomorphism, biotechnology, mega-structure, and metabolism, reflect a level of maturity of the human mind, a stage of progress, an interaction between laws of nature and man, and a better understanding of laws of nature. On describing this process, Warren ${ }^{82}$ states that in both the natural and manmade worlds, we occasionally encounter wonderful forms, mechanisms, and assembly techniques that we quickly recognize as essential or quintessential solutions. Human designers invented some of these great little ideas, but most have evolved through natural process, particularly biology ${ }^{83}$.

In architecture, high-tech despite its up-rooted character, could help in freeing the architect's mind from his attachment to past forms and precedent construction systems that are sometimes against the forces of change and innovation. Creating large spaces and freeing built space from columns, could be considered as an ideal requirement that could not be achieved in the past due to gravity forces and limits of technology. In mosques for instance, the columns are, according to Prophet's recommendations, undesired elements that hinder full use of prayer space ${ }^{84}$. Rows are inevitably cut-off, and preaches of Friday prayer and daily speeches are disturbed as many attendees could not see the speaker. Istanbul mosques, designed by Sinan, give in this regards, a best example of its time regarding response to this criterion. The technique of the large domes was adapted and developed from the existing Byzantine architecture. The use of loudspeakers in calling for prayer also questions the necessity of the minarets beyond their symbolic role. High-tech could help envisaging new ways to respond to this functional requirement. Flexibility in the furniture that increase space use could also be achieved by high-tech for the design of mobile Mihrab, furniture for shoes, rational use of water in ablution, etc. The use of modern material and developed construction techniques is a case in point. Nothing in Muslim theory precludes the use of the latest construction methods and modern design in the building of mosques and other buildings ${ }^{85}$. The computer-based covering of courtyard in the Prophet's mosque in Medina could be an example in this sense.

\section{Regionalism and Neo-vernacular: The Sense of Place}

Regionalism considers societal specificities, climate, geography, and morphological features, as a source of inspiration. Culture and social practices give a "sense of place" to particular locations and a "character" to an environment ${ }^{86}$.

Initially, regionalism played an important role in facing westernization that was imposed by colonialism first and then by secular ideologies that were imposed by most governments. Bridging the gap of under-development was thought to happen only through the destroying of the identity of local societies. Only through this theory that the return to past and local forms was believed to bring remedy to the cultural rupture imposed by colonization, modernization, and universalism in most of the colonized countries ${ }^{87}$.

Reviving the local architecture, although it is sometimes nostalgic, might be part of the cultural policy that aims at healing the "deformed" identity of local societies and in describing remedy to the still-existing and heavy colonial legacy.

Regionalism reflects also the bottom-up approach that contests the exogenous models of development. Deep cultural structures, indigenous materials and local know-how and technology, present together an alternative in most domains of development and constitutes a smooth passage towards progress for less-developed societies ${ }^{88}$. Striking experiences in this regards are that of Hassan Fathy in Egypt, Charles Correa in India, and Geoffry Bawa in Sri-Lanka ${ }^{89}$.

Suha Ozkan" considers that "vernacularism" is different from "modern regionalism". The first refers to architecture that evolved over time in any region and that is therefore limited to existing building types and scales, whereas modern regionalism refers to a contemporary interpretation of local architectures that is not limited by scale, building types or technology ${ }^{82}$. Thus regionalism is not against modernism but is rather against internationalism. Neo-regionalism, and critical regionalism thus bridges the gap between new technology and local culture ${ }^{91}$.

Regionalism in Islamic thought could be, to a large extent, assimilated to the concept of urf previously described. The recognition of societal specificities is enshrined in the work of Muslim jurists. AlShafei for instance was known to have ruled differently when in Iraq and when he resided in Egypt ${ }^{92}$. Besim $H$ also elaborated in his research on the influence of urf on architecture, and its deep impact on the built environment ${ }^{93}$.

However regionalism might turn into an autarky that limits social and cultural forces of local societies in facing the ever-spreading effects of globalization. A symbiosis between universality of and 
regionalism in the light of Islamic thought, would thus present a way of materializing the famous antiglobalization slogan; "thinking globally and acting locally".

\section{Sustainability, Green Movement and Ihsan Thought}

Ecological, green and sustainable architecture are all terms that name the environmental sensibility that had been growing since the last three decades. Starting from the simple quest for energy saving, the movement developed into more pervasive concerns such as social breakdown, economic deficiency, resources depletion and environmental degradation.

In philosophical terms, sustainability could be considered as a major critique to the modern civilization that was promoted and tailored by the Western thought, through its major paradigms; humanism, industrialization, and modernism. On considering nature as a challenging entity and searching for maximization of benefits and comfort, many aspects of the ecological system and social order were affected. Despites its merits, technology is becoming more and more the backbone of our being, but is paradoxically destroying the entire human civilization and its recipient that is Earth. The optimistic definition of the United Nations to sustainability as being: "those paths of social, economic and political progress that meet the needs of the present without compromising the ability of future generations to meet their own needs," ${ }^{94}$ clearly reflects this concern and announces its universality.

In the present Islamic literature, sustainability is at its infant stage due to the technological backwardness, despite the ever-increasing and undesirable effects of industrialization that embraced all countries. However, fundamental sources of the Islamic doctrine abound with glimpses on the environmental issues. Preserving water during ablution, refraining from urinating and discharging in shaded areas where people take rest, refraining from squatting land from public realm, renouncing from cutting trees even in case of war, are examples of such recommendations ${ }^{95}$.

Colonizing earth, 'Imarat al-Ardh, in the Islamic sense, reflects the practical side of the khilafa concept, and thus insures harmony with the laws of nature. Nasr considers in this regard, that ecological movement goes perfectly in pair with the Islamic concept of khilafa $a^{96}$. Misuse of natural resources is considered as a major contravention to Islamic ethics.

However, intensive use of environmental resources for the sake of development, is also recommended in Islam and is thus contrary to the antidevelopment theories of sustainability. The concept of taskheer for instance reflects the raison of all creatures for the sake of Man, and thus justifies its utilitarian use.

Current recommendations for sustainable architecture goes therefore perfectly in pair with the recommendations of Islamic architecture. Old practices in Muslim architecture reflect these recommendations over history and through the wide territory of Islam. Most buildings and spaces in old Muslim cities responded to climatic conditions such as the use of courtyards, wind-catchers, massive adobe walls for its time-lag effect against heat, and reflected social values such as neighborhood sense, humbleness, rational use of space and energy.

\section{Folklore, Popular, Participative Approach and Freedom Theory}

One of the major deficiencies of modernity is its failure in what was believed as social engineering and bureaucracy that accompanied industrial development ${ }^{97}$. The emergence of squatter settlements and informal sector despite the strong commitment of governments and professionals, and huge financial resources allocated to face the massive needs for housing used in these policies, opened large debate on the capabilities of the technology and the progressive ideology to solve problems of humanity ${ }^{98}$.

On the ground, the share of the built environment controlled from professionals and governments has never been more than $5 \%$ on the face of earth. So it has never been consciously designed ${ }^{99}$. A similar failure could also be seen in the quality of the living environments ${ }^{100}$. The undeniable success in community spirit and popular initiative in the squatter settlements, the creative talents of layman in building and organizing his home and achieving selfsatisfaction away from authorities and professionals presented a new alternative in coping with human needs ${ }^{101}$

Many concepts such as self-help, popular, participative, democratic, anarchist, and neo-vernacular that Jenks named self-traditionalists, have thus emerged together as a set of alternatives to the technocratic dominating philosophy ${ }^{102}$. The backbone idea of this trend is that the environment, people and nature, always act as self-regulating systems, with endogenous rules governing them.

Even within the industrial context, self-tradition approach has the advantage of personalizing mass-produced items, such as houses. Incorporating changes often throws up diverse and rich juxtapositions that was denied by the formal design. At the management level, participation in the industrial context permits the combination of freedom needed by users and control exercised by authorities.

In Muslim cities and in all pre-industrial and pre-bureaucratic societies, people's participation 
and their freedom in building and organizing their environment has always been the tradition. In Islamic thought this tradition reflects the concept of freedom and autonomy that Shariaa defended under the principle of private legal power, wilaya khas$s a^{103}$.

A critical balance between the authority, the professionals, and the community should therefore be set and roles should be redefined for the built environment to bring back its harmony and balance.

\section{Conclusion}

Islamization of knowledge is a concept that bridges the gap between the Islamic thought that is too often confined in its traditional form and the contemporary Western knowledge. Despite the merits and benefits of this latter, it is believed that it is mostly based on secular principles and has disastrous effects that should be corrected and redirected through the Islamic knowledge.

Architecture is one of the major domains of this knowledge where most of values and sciences meet and thus reflects such a clash. The need for its Islamization emerges on one side from the comprehensiveness of the Islamic religion and, on the other, from the growing quest for identity from Muslim societies and individuals.

In history, a similar process of Islamization took place during the early time of Islam where preIslamic civilizations were absorbed and gave birth to the presently known Muslim architecture(s). It was only after decades and centuries of adoption, use and re-use of pre-existing architectures that original output took place.

Despite the high degree of diversity that characterizes these outputs, due to the difference in pre-Islamic legacies, the evolution processes and the geographic conditions, common principles that derive from the Islamic doctrine stand behind these outputs and thus constitutes their common platform.

Islamization of architecture is founded on mechanisms that stem from the essence of the Islamic thought and that apply to many other disciplines. Contemporary architecture(s) provide a wealth of human knowledge that should also be subjected to Islamization, a critical process of filtering and re-theorizing that relies on these mechanisms. Many movements such as sustainable and participative trends could for instance be fully adopted while others such as deconstruction and minimalism could be remodeled according to the Islamic ethics.

\section{Notes and References}

1 It was initially used by Al-Attas (1978, “Islam and Secularism") and Al-Faruqi (1982, "The Malaise of the Ummah").
2 A. Abu-Sulayman. 1989. "Orientation Guidelines for the International Conference on Islamization of Knowledge" in Towards Islamization of Disciplines Series N 6. Herndon Virginia: The International Institute of Islamic Thought. p.13 L. Stenberg. 1996. The Islamization of Science: Four Muslim Positions Developing an Islamic Modernity. Lund: Lund Studies in History of Religions

3 Syed M. Naquib Al-Attas. 1995. Prolegomena to the Metaphysics of Islam: An Exposition of the Fundamental Elements of the Worldview of Islam. Kuala Lumpur: The International Institute of Islamic Thought and Civilization (ISTAC). p. 38

4 Syed M. Naquib Al-Attas. 1978. Islam and Secularism, $2^{\text {nd }}$ edition. Kuala Lumpur: The International Institute of Islamic Thought and Civilization (ISTAC).

5 Stefano Bianca. 1981. "Islam and Urban Development", in The International Institute of Islamic Thought (IIIT) Towards Islamization of Disciplines p. 497-504, Herndon, USA: International Islamic Publishing House

6 Islam at present, is the fastest growing monotheistic religion and consequently more institutions and premises such as mosques and schools are being established by/for the followers than are in any other faith. Many stores, old churches and houses in western countries such as in France and U.K. were purchased by Muslim associations and transformed into Qur'anic schools, prayer halls and Islamic centres.

7 M. Frishman. 1994. "Islam and the Form of the Mosque", in M. Frishman \& Hasan Uddin Khan (ed.). The Mosque; history, architectural development and regional diversity. London: Hudson \& Thames. p.17-42

8 Amos Rapoport. 1969. House, Form and Culture. Englewood Cliffs, New Jersey: Prentice-Hall

Amos Rapoport. 1990. History and Precedent in Environmental Design. NY \& London: Plenum Press

9 Despite the permanent link of Arabs with the great civilizations in Yemen and Shaam, these most sacred buildings were kept simple in a way to stress the new raising values that overpass materiality.

10 KAC. Creswell. 1989. A Short Account of Early Muslim Architecture. Cairo: The American University in Cairo Press. p. 3

11 KAC. Creswell. 1989. A Short Account of Early Muslim Architecture. Cairo: The American University in Cairo Press. p. 4-5

M. Frishman. 1994. "Islam and the Form of the Mosque", in M. Frishman \& Hasan Uddin Khan (ed.). The Mosque; history, architectural develop-ment and regional diversity. London: Hudson \& Thames. p.17-42.

12 KAC. Creswell. 1989. A Short Account of Early Muslim Architecture. Cairo: The American University in Cairo Press. p. 3 
13 M. Ben-Hamouche. 2004. "From Kufa to Blida Modelling Muslim New Towns Experience". Journal of King Saud University Vol. 17, Arch. \& Planning, p. 25-42, Riyadh: KSU

14 KAC. Creswell. 1989. A Short Account of Early Muslim Architecture. Cairo: The American University in Cairo Press. p. 4

15 Ibn Saad records that the prophet said: "The most unprofitable thing that eaten up the wealth of a Believer is building." Tabakat Ibn Saad I2, p. 181, II. 7-8, also VIII p. 120 II 7-8. Quoted by Creswell KAC. 1989. p.4.

16 This phenomenon was misinterpreted by many orientalists for being a sort of plagiarism.

17 Charles Correa. 1994. Vistas Architecture for Islamic Societies Today James Steel ed. London. London: Academy Editions. p. 15

18 KAC. Creswell. 1989. A Short Account of Early Muslim Architecture. Cairo: The American University in Cairo Press. p. 6-7

C. Correa. 1994. Vistas Architecture for Islamic Societies Today James Steel ed. London. London: Academy Editions. p. 15

19 KAC. Creswell. 1989. A Short Account of Early Muslim Architecture. Cairo: The American University in Cairo Press. p. 8

20 For instance, the mihrab of the mosque that was during the prophet a simple indication on the wall turned into a niche that reflects the form of the iwan (Creswell: 15).

21 KAC. Creswell. 1989. A Short Account of Early Muslim Architecture. Cairo: The American University in Cairo Press. p. 46-51

22 JM. Bloom. 1991. "Creswell and the Origins of the Minaret", in Muqarnas III an Annual on Islamic Art and Architecture.

RJH. Gotthiel. 1910. "The Origin and History of the Minaret", in Journal of the American Oriental Society, Vol. 30, No. 2, Mar. 1910, p. 132-154

23 AK. Lake. 1937. "The Origin of the Roman House", in American Journal of Archeology Vol. 41, No. 4, Oct.-Dec., p. 598-601

24 In this paper, Muslim architecture is considered as the physical output that reflects practices of Muslim societies and individuals in response to the teachings and principles of Islam. While Islamic architecture is the set of principles that derive from Islamic doctrine and that shape the conduct of Muslims and thus dictate Muslim architecture(s).

25 Ismail Serageldin. 1996. "Faith, Development and the Built Environment", in Almanac. p. 465

26 Ismail Serageldin. 1996. "Faith, Development and the Built Environment", in Almanac. p. 466

27 Ismail Serageldin. 1996. "Faith, Development and the Built Environment", in Almanac. p. 467

28 Ismail Serageldin. 1996. "Faith, Development and the Built Environment", in Almanac. p. 467

29 Ismail Serageldin. 1996. "Faith, Development and the Built Environment", in Almanac. p.469

30 This action is also known in Islamic term as 'Imara, Isti'imar from which interestingly for architects, the discipline of Architecture in
Arabic, Imara and/or handassa mi'mariyya, derives. However, the meaning of term nowadays has been deeply altered due to its (mis)-use for connoting colonialism, isti'imar.

31 International Institute of Islamic Thought (IIIT). 1995. Islamization of Knowledge, General Principles and Work Plan. Herndon Virginia. p. 43

32 International Institute of Islamic Thought (IIIT). 1995. Islamization of Knowledge, General Principles and Work Plan. Herndon Virginia. p. 36

33 A. al-Najjar. 1997. "Al-Eyman wa al-Umran", in Islamiyyat al-Maarifah 8-(2). p.39-84

N. Salingaros. 2004. Anti-Architecture and Deconstruction. Solingen: UMBAU-Verlag. p. 94

34 "Behold, your Lord said to the angels, "I will create a vicegerent on Earth" (Quran 01:31). " $O$ ' people, We have created you (all) of a single pair, a male and female, and We have constituted you into tribes and nations that you may know one another. Nobler among you in the estimate of Allah is the more virtuous." (Quran 49:13)

35 International Institute of Islamic Thought (IIIT). 1995. Islamization of Knowledge, General Principles and Work Plan. Herndon Virginia. p. 46-51

36 Sayyed Hossein Nasr. 1996. Religion and the Order of Nature. Oxford: Oxford University Press. p. 6

37 Syed M. Naquib Al-Attas. 1995. Prolegomena to the Metaphysics of Islam: An Exposition of the Fundamental Elements of the Worldview of Islam. Kuala Lumpur: The International Institute of Islamic Thought and Civilization (ISTAC).

38 Al-Attas stated it differently: "the multiplicity of existents does not impair the unity of existence, for each existent is a mode of existence and does not have a separate ontological status." (Al-Attas, 1995)

39 KW. Warren. 2000. Design Paradigms: a sourcebook for creative visualisation. New York: John \& Wiley. p. 4

40 Sayyed Hossein Nasr. 1996. Religion and the Order of Nature. Oxford: Oxford University Press.

41 Amos Rapoport. 1990. History and Precedent in Environmental Design. NY \& London: Plenum Press.

42 KW. Warren. 2000. Design Paradigms: a sourcebook for creative visualisation. New York: John \& Wiley

43 CA. Doxiadis. 1969. Existics: An introduction to the science of settlements. London: Hutchinson

44 Hasan Langgulung. 1995. Research in Psychology: Toward An Ummatic Paradigm in Roward Islamization of Disciplines. Virginia: IIIT Herndon. p. 115-127

45 Such Ends are also classified in a priority order that allows compromising in case of clashes. In this sense, the material Property End comes at the bottom of the rank, while the religion 
comes first. In the case of an acute need for housing for instance and the availability of private land and unoccupied shelters, the ruler could oblige the owners to provide the shelters based on the juridical priority of human lives over private properties.

46 Jurists consider that the previous set of Ends together with Urf enable Shariaa to embrace all aspects of human life that the apparently limited number of fundamental texts (verses of Quran and sayings of the prophets) couldn't cover (Al-Shatibi D. 790 A.H).

47 In Verse 7:199: "Take things at their face value and bid to what is customary, i.e. accepted by local tradition, ..."

48 Al-Shatibi. 2002. Al Muwafaqat fi Usul alShariaa Dar al-Kitab al-Arabi (d. 790 AH). Beirut. p. 382

49 Charles Correa. 1994. Vistas Architecture for Islamic Societies Today James Steel ed. London. London: Academy Editions

Kenneth Frampton. 1986. "Place, Form and Cultural Identity" in Domus \#673, June 1986, pp 19-24

Kenneth Frampton. 1983. "Towards a Critical Regionalism: Six points for an Architecture of Resistance" in The Anti-Aesthetic, ed. Hal Foster, Washington: Bay Press

50 Besim S. Hakim. 1994. "The 'Urf' and Its Role in Diversifying the Architecture of Traditional Islamic Cities", in Journal of Architectural \& Planning Research 11:2, Summer 1994, p. 108127

51 Amos Rapoport. 1990. History and Precedent in Environmental Design. NY \& London: Plenum Press. p. 17

52 M. Al-Asad. "Application of Geometry" in Frishman, p. 55-70

53 This approach was developed in consequence to the teaching load I had at the University of Bahrain during the four last semesters. Confrontations were often made between the Islamic thought and the Western knowledge while I was teaching Islamic Architecture and Contemporary Architecture simultaneously.

54 Charles Jencks. 2000. Architecture 2000 and Beyond: Success in the art of prediction. New York: Wiley-Academy. p. 3

55 Charles Jencks. 1993. Architecture Today. London Academy Editions. p. 111

56 Charles Jencks. 2000. Architecture 2000 and Beyond: Success in the art of prediction. New York: Wiley-Academy. p. 66-67

57 Charles Jencks. 2000. Architecture 2000 and Beyond: Success in the art of prediction. New York: Wiley-Academy. p. 66

58 Paul-Alan Johnson. 1994. The Theory of Architecture Concepts, Themes \& Practices. New York: Van Nostrand Reinhold. p. 21

59 Paul-Alan Johnson. 1994. The Theory of Architecture Concepts, Themes \& Practices. New York: Van Nostrand Reinhold. p. 21

60 John Brinckerhoff Jackson. 1984. Discovering the vernacular landscape. New Haven: Yale
University Press. p. xi

Amos Rapoport. 1990. History and Precedent in Environmental Design. NY \& London: Plenum Press. p. 58

61 Abdullah Yusuf Ali. 1983. The Holy Qur'an: Translation and Commentary. Surah 20:99, 7: 101, 22:46, 12:3. Maryland: Amana Corporation

62 Amos Rapoport. 1990. History and Precedent in Environmental Design. NY \& London: Plenum Press. p. 94

63 Ibn Khaldun, Franz Rosenthal, N.J. Dawood (ed). 1967. The Muqaddimah: An Introduction to History. New Jersey: Princeton University Press.

64 James Steele. 1997. Architecture Today. New York: Phaidon. p. 110

65 James Steele. 1997. Architecture Today. New York: Phaidon. p. 110

66 James Steele. 1997. Architecture Today. New York: Phaidon. p. 113

67 In a verse of Quran, Muslims are warned from preferring "houses they own" than God and His prophet. Al-Qarafi Al-Furuq Vol 4, p162-163 considers that zuhd doesn't necessarily mean poverty. A pious man can be zahid although he is reach as all his richness doesn't overwhelm his reason and love to God.

68 A complete Surah in the Quran is in fact named Az-Zukhruf (adornments). [And were it not that (all) men might become one (evil) way of life, We would provide, for everyone that blasphemes against (Allah) Most Gracious, silver roofs for their houses, and (silver) stair-ways on which to go up. (33) And (silver) doors to their houses, and thrones (of silver) on which they could recline (34) And also adornments of gold. But all this were nothing but conveniences of the present life: the Hereafter, in the sight of thy Lord, is for the Righteous. (35) (Quran AzZukhruf 43: 33-35). Sophisticated living and decoration in Islamic thought often stand in contrast with zuhd (asceticism) and is often regarded as opposing to the spirit of Islam.

69 Jonathan Bloom \& Sheila Blair. 1997. Islamic Art. London: Phaidon Press. p. 23

70 Jonathan Bloom \& Sheila Blair. 1997. Islamic Art. London: Phaidon Press. p. 15

M. Frishman. 1994. "Islam and the Form of the Mosque", in M. Frishman \& Hasan Uddin Khan (ed.). The Mosque; history, architectural develop-ment and regional diversity. London: Hudson \& Thames. p.32

71 Ironically, tensile structure that was inspired from the Bedouin tent, is now considered as one form of minimalism in architecture that provide maximum space with minimum material.

72 Nikos Salingaros. 2004. Anti-Architecture and Deconstruction. Solingen: UMBAU-Verlag. p. 95

73 According to Salingaros (2004) the deconstructtivist philosophy upon which those architects depend is totally unscientific and that has nothing to do with the new science of complexity. 
74 Ilya Prigogine. 1996. The End of Certainty; Time, chaos and the new laws of nature. New York: The Free Press. p. 1-56

AB. Cambęl. 1993. Applied Chaos Theory: A paradigm for complexity. Boston: Academic Press.

75 Ilya Prigogine. 1996. The End of Certainty; Time, chaos and the new laws of nature. New York: The Free Press. p. 10

76 Paul-Alan Johnson. 1994. The Theory of Architecture Concepts, Themes \& Practices. New York: Van Nostrand Reinhold. p. 20

AB. Cambęl. 1993. Applied Chaos Theory: A paradigm for complexity. Boston: Academic Press. p. 31

77 Abdullah Yusuf Ali. 1983. The Holy Qur'an: Translation and Commentary. Surah 67: 3-4. Maryland: Amana Corporation

78 The Sovereignty, Control 67:4 "Again turn thy vision a second time: (thy) vision will come back to thee dull and discomfited, in a state worn out".

79 In fact in many verses of the Qur'an especially the first one that is recited at least 5 times a day, believers ask God to Guide us to the straight path! In a prophet saying: he took a stick designed one straight line and many others deriving from it and then said, the straight one is the path of God and the others are astray that you shouldn't follow. However most streets in Muslim cities are irregular, which were an outcome of the constraints of the site, the earth, to be considered!

80 M. Ben-Hamouche. 2007. Urban Fabric In Traditional Muslim Cities: Importing the Old Wisdom to our New Settlements. $2^{\text {nd }}$ Symposium on Arab Muslim Cities. Damascus: 22-24 October 2007

81 Many legal opinions have been issued by contemporaneous Muslim scholars regarding bio-technology, medicine etc.

82 Warren K. Wake. 2000. Design Paradigms: a sourcebook for Creative Visualisation. New York: John \& Wiley. p. 2

83 Charles Jencks. 2000. Architecture 2000 and Beyond: Success in the art of prediction. New York: Wiley-Academy. p. 73

Warren K. Wake. 2000. Design Paradigms: a sourcebook for Creative Visualisation. New York: John \& Wiley. p. 4

84 This is opposite to some erroneous metaphysical explanations that consider multiplicity of columns in the prayer hall as a sign of infinity admired by Muslims.

85 Oleg Grabar. "The mosque in Islamic society today", in M. Frishman \& Hasan Uddin Khan (ed.). The Mosque; history, architectural development and regional diversity. London: Hudson \& Thames. p. 245

86 Charles Correa. 1994. Vistas Architecture for Islamic Societies Today James Steel ed. London. London: Academy Editions. p. 13
Ismail Serageldin. 1996. "Faith, Development and the Built Environment", in Almanac. p. 72

87 Hasan Uddin Khan. "An overview of the contemporary mosques", in $M$. Frishman \& Hasan Uddin Khan (ed.). The Mosque; history, architectural development and regional diversity. London: Hudson \& Thames. p. 248

88 EF. Schumacher. 1973. Small is Beautiful: Economics as if People Mattered. New York: Harper Perennial

Charles Correa. 1994. Vistas Architecture for Islamic Societies Today James Steel ed. London. London: Academy Editions. p. 14

89 James Steele. 1997. Architecture Today. New York: Phaidon

90 Süha Özkan. 1985. "Introduction - Regionalism within Modernism", in Robert Powell (ed.). Regionalism in Architecture. Singapore: Concept Media/The Aga Khan Award for Architecture.

91 Charles Correa. 1994. Vistas Architecture for Islamic Societies Today James Steel ed. London. London: Academy Editions. p. 14

Kenneth Frampton. 1986. "Place, Form and Cultural Identity" in Domus \#673, June 1986, pp 19-24

Kenneth Frampton. 1983. "Towards a Critical Regionalism: Six points for an Architecture of Resistance" in The Anti-Aesthetic, ed. Hal Foster, Washington: Bay Press

92 Ismail Serageldin. 1996. "Faith, Development and the Built Environment", in Almanac. p.72

93 Besim S. Hakim. 1994. "The "Urf" and Its role in diversifying the architecture of traditional Islamic cities", in Journal of Architectural \& Planning Research 11:2. Summer, 1994. p. 108127.

94 United Nations. 1987. Report of the World Commission on Environment and Development General Assembly.

95 M. Ben-Hamouche. 2004. "From Kufa to Blida Modelling Muslim New Towns Experience", in Journal of King Saud University Vol. 17, Arch. \& Planning. Riyadh: KSU. pp. 25-42

96 Sayyed Hossein Nasr. 1997. Man and Nature: The Spiritual Crisis in the Modern Man. Reviewed ed. Chicago: Kazi Publications

97 Charles Jencks. 2000. Architecture 2000 and Beyond: Success in the art of prediction. New York: Wiley-Academy. p. 72

98 Charles Jencks. 2000. Architecture 2000 and Beyond: Success in the art of prediction. New York: Wiley-Academy. p. 77

99 Constantinos Doxiadis. 1969. Ekistics: An introduction to the science of settlements. London: Hutchinson. p. 7-18

Charles Jencks. 2000. Architecture 2000 and Beyond: Success in the art of prediction. New York: Wiley-Academy. p. 51

100 Constantinos Doxiadis. 1969. Ekistics: An introduction to the science of settlements. London: Hutchinson. p. 12 
JFC. Turner. 1972. Housing As a Verb; freedom to build. JFC Turner and Fischter R. (ed.) New York: MacMillan. p. 148-175

101 Nabeel Hamdi. 1991. Housing Without Houses: Participation, Flexibility, Enablement. New York: Van Nostrand Reinhold

Constantinos Doxiadis. 1969. Ekistics: An introduction to the science of settlements. London: Hutchinson. p. 318-326
102 Charles Jencks. 2000. Architecture 2000 and Beyond: Success in the art of prediction. New York: Wiley-Academy. p. 51

103 M. Ben-Hamouche. 2003. "Decision-Making System and Urban Geometry in Traditional Muslim Cities: The Case of Algiers". In Journal of Architectural and Planning Research. Vol. 20, No 4, Winter 2003, p. 307-322. Chicago USA 